\title{
Realisation of Indirect Speech Acts in Online Job Advertisements
}

Ke y words: job advertising; illocutionary acts; indirect speech acts; ambiguity; persuasion

Słowa klucze: ogłoszenia rekrutacyjne; akty illokucyjne, pośrednie akty mowy; niejednoznaczność; perswazja

\section{Introduction}

Recruitment through advertising is probably the most frequently used method of attracting candidates in the last few decades (e.g. Cooper et al. 2003; van Meurs 2010). The aim of recruitment advertising is to "attract the attention of the best candidates who may not even be seeking another role, while not raising false expectations and allowing a healthy amount of selfselection" (Secord 2003: 355); notwithstanding, job advertisements are also meant to project a positive image of an organisation in the outside world (ibid.). Since the design and content of job ads contribute significantly to how a company is perceived by job market participants, great care is taken by employers to ensure that vacancies are advertised in a professional, attractive and, most importantly, effective way.

In the recruitment process, job market participants play roles similar to those performed by sellers and buyers in a sales transaction: a job seeker is 
both a product that some company may wish to buy, and a seller trying to sell him/herself on the job market (Tokarz 2006); on the other hand, a potential employer also performs a double role: that of a seller aiming to sell the job offered, and that of a buyer interested in attracting the most valuable candidates to the position advertised. Thus the mechanisms used by employers in job announcements are, to a large degree, parallel with those incorporated in product or service advertising.

Drawing on the cognitive approach to the speech act theory, this paper aims to investigate which types of speech acts play a dominant role in the texts of online job advertisements, to what extent those acts are realised indirectly, and what purposes this indirectness may serve. The classification and distribution of speech acts in the material analysed seem to reflect the complex nature of the communicative purpose behind job advertising, combining at least two aspects: informing and persuading (see e.g. Łącka-Badura 2011).

\section{Speech act classification and interpretation - 'classical' taxonomy ${ }^{1}$}

Considered to be based on objective criteria, the widely applied 'classical' (and very influential) typology divides speech acts into five categories:

- Representatives (Assertives) - the point of which to state what the speaker believes to be the case or not, representing some states of affairs, e.g. statements, affirmations, denials

- Directives - aimed at directing the addressee towards doing something, e.g. orders, requests, permissions, commands, invitations

- Commissives - the illocutionary point of which consists in the speaker committing him/herself to perform a certain future action, e.g. promises, commitments, guarantees, pledges

1 It should be noted that the concept of speech acts was initially developed by Austin (1975) and his followers in and for the domain of short spoken utterances. Being longer, more complex, providing little or no evidence of the reader's reaction, written texts are far more difficult to analyse and interpret in terms of the speech act theory than brief spoken utterances. Nevertheless, many written genres are also regarded as speech acts (see e.g. Bazerman 2004; Skowronek 2001), comprising a variety of micro-speech acts contributing to the overall message rendered in the macro-act. It seems therefore justified to apply the speech act theory to the present analysis of illocutionary acts in recruitment announcements. 
- Expressives - whose illocutionary point is to express a certain emotional state of the speaker, e.g. thanks, congratulations, apologies

- Declaratives - the point of which is that something is brought about in the world by virtue of someone's declaring it, e.g. a referee saying "You are out" to a football player during a match, or a priest declaring: "I now pronounce you husband and wife" during a wedding ceremony (Searle 1970; Yule 1996).

- Illocutionary acts are understood as the acts done in speaking (where saying equals doing ); the illocutionary aspect or force of speech acts is related to the intention or communicative purpose of the speaker, to "what is directly achieved by the conventional force associated with the issuance of a certain kind of utterance in accord with a conventional procedure" (Levinson 1983: 237).

It is widely acknowledged in the literature that a large proportion of the illocutionary acts are indirect speech acts, i.e. acts in which speakers "perform one illocutionary act implicitly by way of performing another illocutionary act explicitly" (Searle \& Vanderveken 1985: 117)2. In other words, indirect speech acts demonstrate no "explicit match" "between a sentence type and its corresponding force" (Cap 2010: 218). As G.P. Brown argues, "[i]ndirect speech act forms range from highly conventionalised to apparently free forms. It appears that no single, simple set of generalisations can adequately capture the complexity of indirect speech acts" (1980: 150).

The question why speakers often tend to use indirect rather than direct speech acts is another issue addressed by linguists dealing with the speech act theory. One of the main motivations, as proposed by Searle (1970), Brown (1980), and Yule (1996), is politeness which, at least in English, is more effectively expressed through indirect rather than direct speech acts. Notwithstanding, indirectness is also widely recognised as a powerful persuasive tool, supporting other mechanisms of persuasion, not only in messages which are traditionally classified as persuasive (e.g. marketing advertisements), but also in other texts in which persuasion plays an important role (e.g. recruitment ads).

2 As a matter of fact, it has been pointed out in several studies that most speech act usages are indirect (Cap 2010). 


\section{The cognitive approach}

There is much controversy around the classification of illocutionary speech acts, and the numerous approaches to various degrees follow or oppose the above mentioned 'classical' typology (see e.g. Hernandez 2001; Levinson 1983). The methodology adopted for the present study is that postulated by the cognitive approach, which offers a concept of speech acts as basic units of communication subject to principles generally underlying human cognitive processes (see e.g. Asher and Lascarides 2001; Hernandez 2001; Sokołowska 2001). Without obliterating the classical taxonomy, cognitive linguists propose that the categories should be treated as prototypes (models conforming to the whole set of felicity conditions), a reference point aimed at enhancing the degree of systematicity and organisation of the analysis, rather than drawing strict demarcation lines between certain speech act types. Moreover, the boundaries between speech act categories are viewed as fuzzy, therefore their directness / indirectness, as well as assignment to particular categories, are a matter of degree; certain speech acts bear an ambiguous / double / manifold illocutionary force depending on the context, including instances whose illocutionary force is vague or indeterminate ${ }^{3}$.

Following from the above, Searle's 'classical' taxonomy of speech acts is employed in the present study as the prototypical model, allowing an attempt at the breakdown of the speech acts into some specific categories. Although the analysis demonstrates that a large proportion of speech acts in job announcements are realised indirectly, and in many cases the boundaries between particular categories are blurred, yet for the sake of clarity and organisation the semantic and syntactic structures of utterances have been chosen as the criteria on which the categorisation has been based. Thus the classification into the prototypical types of illocutionary speech acts (Representatives, Directives, Commissives, Expressives and Declaratives) has determined grouping of the findings into respective sections, with Expressives and Declaratives grouped in one block as they are virtually absent in the corpus. A separate section is devoted to the speech acts performed by the syntac-

3 See Witczak-Plisiecka (2009) for an extensive discussion on the difference between ambiguity and vagueness. 
tic form of interrogatives, and another one to those acts whose illocutionary force is manifold and thus difficult to classify.

In line with the premises of the micropragmatic approach, the term speech acts is used throughout the study with reference to the numerous micro-acts (both simple and complex, analysed at the utterance level) contributing to the entire macro-speech-act (or speech event) of job advertising (cf. Cap 2010).

\section{Distribution of speech acts in online job advertisements}

A corpus of 100 online recruitment ads has been analysed for the purposes of this study. To ensure sufficient variety and diversity of the material, 60 ads were randomly selected in the period from August to October 2010 from among announcements that appeared in the Internet editions of three major UK newspapers (The Daily Telegraph, The Guardian, The Times), and the remaining 40 were found on two of the leading UK job portals (www.jobsite.com and www.totaljobs.com). To enhance objectivity, utterances which were both produced by and related to recruiters or job advertising agencies (acting as intermediaries between employers and employees) have been excluded from the analysis.

The present section accounts for the distribution of micro-speech acts in the corpus.

\subsection{Representatives}

Apparently, representative illocutionary acts constitute the largest and most heterogeneous group of the speech acts found in the corpus. A total of 687 speech acts whose syntax, semantics and, in the majority of instances, function seem to justify their qualification as Representatives have been identified in the material.

\section{a) Representatives acting as representatives}

The largest group of Representatives includes 243 micro-acts with the illocutionary force of asserting and stating the qualifications, skills, and experience that potential candidates must possess if they wish to be appointed. The pragmatic 'test' (rephrasing the utterances in an attempt to identify a set of common performative verbs used to denote employers' requirements) has 
demonstrated that all of the utterances may logically be rephrased in the following way:

We state / assert that we will only accept candidates who possess the skills, qualifications, and experience specified.

Examples include the following:

(1) You will have strong copywriting skills and agency management experience, as well as ... (JA3) ${ }^{4}$

(2) You should be qualified to at least degree level or equivalent in metallurgy or materials science, preferably ... (JA7)

(3) We are looking for strong candidates with a proven track record of success at a management level ... (JA9)

(4) This is a target related position which requires someone with good communication skills, self-motivated, computer literate and ... (JA8)

The second largest segment of Representatives (found in 93 of the advertisements examined) comprises 193 utterances performing the acts of describing the tasks, duties and responsibilities that the position entails. Similarly to the 'requirements' group, the micro-acts classified as 'job descriptions' have passed the pragmatic 'test' which demonstrates that they may logically be rephrased as follows:

We state / explain that the candidates will be expected /required to perform the following tasks if they are appointed.

The extracts below exemplify how these micro-acts are realised linguistically:

(5) You will work with Channel partners to create and deliver partner specific business plans ... (JA2)

4 The abbreviation JA is used throughout the paper meaning Job Advertisement. The texts are numbered from 1 to 100, thus e.g. JA3 denotes Job Advertisement number 3 in the corpus. 
(6) The purpose of this role is to deliver the Group strategy with regard to new business development and relationship management.

The Representatives performing the illocutionary acts of informing and/ or instructing constitute a group of 97 utterances in the corpus. The majority of them (59) refer to the recruitment process and application procedure, for instance:

(7) Recruitment process is scheduled for 29th July and will include an editorial exercise, presentation and interview. (JA26)

Such a large proportion of Representatives referring to employers' requirements, describing the scope of responsibilities and tasks that the position entails, as well as informing / instructing the candidates how to apply, most probably results from the core communicative function of job advertising. However, importantly for the present study, only 19 of the 'informative' Representatives may be regarded as neutral information about the employing organisation. The remaining 11 utterances of this kind seem to prepare the ground for the subsequent acts of boasting, as illustrated below:

(8) These days, financial services are rarely out of the headlines. (JA55)

The above utterance is followed by an easily recognisable act of boasting:

(9) This makes it even more important that at Nationwide, we offer the most competitive products at the most competitive prices. (JA55)

Boasting, inherent to employers' positive self-presentation (and, consequently, to the overall persuasive appeal of job ads) is discussed in the following sub-section.

\section{b) Representatives realising the acts of boasting - employers' self-presen- tation}

As has been mentioned earlier, the function of job advertisements is not merely to inform potential candidates about the requirements and responsi- 
bilities involved in the positions advertised, but also, sometimes even more importantly, to encourage / persuade the most valuable candidates to apply, as well as to create or reinforce the employer's positive image in the eyes of all job market participants. The representative acts that serve the persuasive purpose of job ads are those of employers boasting about their position on the market, the uniqueness of the product range and quality, high ethical standards and the exceptional care taken of their customers and employees. The illocutionary force of those utterances is mostly encoded in assertions which, on the surface, provide candidates with information about their potential employers.

The possible explications for the micro-acts of boasting are provided below:

I say that I deserve positive reputation because of what I do/ have done;

I think you / others understand that I deserve to be appreciated, admired, envied.

A total of 133 Representative utterances performing the acts of boasting have been found in 70 of the advertisements analysed. Their structures and functions are similar to those identified in the 'central' persuasive/promotional genre: product advertising (cf. Skowronek 2001). Examples of such utterances include the following:

(10) Admiralty is a global leader in the provision of information to the marine industry. (JA2)

(11) We are small enough to care and large enough to have impact. (JA4)

\section{c) Representatives acting as Commissives}

Among the micro-acts which, semantically and syntactically, may plausibly be classified as Representatives, a group of 67 acts whose illocutionary force is that of Commissives has been identified in the corpus. Commissives "operate a change in the world by means of creating an obligation (...) in the speaker" (Mey 1994: 164), thus their illocutionary point consists in the addresser committing him/herself to perform a certain future action. In the job advertisements studied, the Commissives disguised as Representatives perform the acts of promising and offering. 
Recognising the act of offering is a simple task - the verb to offer is used in 13 utterances which seemingly state facts or provide information (although not in the first person, which is the case in prototypical offers):

(12) The package offers a competitive basic salary, unlimited commission potential and a company car. (JA4)

The remaining utterances have a semantic and syntactic form of statements referring to the future or passing information about the benefits to be gained by prospective employees, yet they may logically be rephrased as follows:

We promise that you will receive / enjoy / be given ... ( employee benefits) We promise that you won't regret applying for this position because ...

The extract below instantiates such an indirect promise:

(13) As you learn and demonstrate reliability and results, you will become eligible for advancement opportunities including ... (JA67)

Promising benefits being inherent to persuasive discourse, the indirect promises clearly contribute to the persuasive impact of job ads (cf. Łacka-Badura 2011).

\subsection{Commissives}

As mentioned in the previous sub-section, the illocutionary point of commissive speech acts consists in the speaker committing him/herself to performing a certain future action. The corpus of the job advertisements studied comprises only 11 utterances (found in 10 ads) which explicitly perform the illocutionary acts of offering (10 instances, of which 2 are tentative offers) and guaranteeing (1 instance), for example:

(14) In return we offer a great salary, pension, travel (optional), benefits and the opportunity to create dramatic change for children. (JA23) 
The verb to offer is used in more utterances in the corpus, however, given that it refers to the range of products or services provided to the company customers, and not to the benefits offered to the future employees, its illocutionary force has been interpreted as that of stating / boasting, contributing to the projection of a positive image of the organisation.

However unimpressive the number of direct Commissives may appear, the commissive illocutionary point seems to permeate the texts of the job advertisements studied. The persuasive aspects of promising and offering are conveyed indirectly in a large group of Representatives, as was demonstrated in sub-section 4.1.

\subsection{Directives}

Directive speech acts are said to "embody an effort on the part of the speaker to get the hearer to do something, to 'direct' him or her towards some goal (of the speaker, mostly)" (Mey 1994:164). Found in 79 of the announcements studied, the 138 utterances that have the semantic and syntactic form of Directives (i.e. which use the performative verbs naming a directive illocutionary force and/or use the Imperative mode) are distributed as follows: 25 instances of instructions concerning the application procedure, using the Imperative, 55 instances of polite instructions concerning the application procedure, 19 instances of requests / polite instructions (on the surface), performing the acts of informing about the job and application procedure, and 5 instances of recommendations (on the surface), acting as statements of requirements. Examples include the following:

(15) Reply with full c.v. in complete confidence by e-mail to ... (JA57)

(16) To apply please send a copy of your CV and covering letter stating the position you are applying for. (JA74)

(17) We ask that ALL applicants meet the candidate eligibility criteria, although we do not require ... (JA73)

(18) We also recommend strong communication skills and smart appearance ... (JA76)

Most of the remaining utterances which have the semantic and syntactic structure of directive speech acts, mostly commands / invitations / sugges- 
tions, are in fact emotionally charged appeals which perform a persuasive role similar to the function that slogans fulfil in product advertisements, encouraging addressees to take action, at the same time implying positive selfpresentation:

(19) Don't miss out on this fantastic corporate communications career opportunity within this prestigious retail finance organisation. (JA29)

(20) Take this mouth-watering opportunity today. (JA52)

(21) Look no further because this is the job for you! (JA78)

\section{a) Interrogative structures}

An interrogative syntactic structure is commonly associated with the illocutionary force of a question. There are, however, numerous departures from this prototype, for instance in requests, where the interrogative form is often intended to serve politeness functions. In the job advertisements analysed, 33 utterances have been identified whose syntactic interrogative structure serves purposes other than asking a question (the latter being understood as an utterance aimed at finding out whether a proposition is true, or acquiring some information). The illocutionary point of the majority of such interrogative forms in recruitment ads is similar to that identified for 'questions' used in product and service advertisements, for instance:

(22) Are you looking for a great opportunity where you can make your mark and money? (JA4)

(23) Hungry For Success? (JA5)

The examples provided above are most probably used to attract readers' attention and, indirectly, perform the act of promising that the benefits suggested in the propositions will be available to those who apply for the vacancies and are selected to become prospective employees.

Other instances of interrogative structures comprise the acts of boasting:

(24) Would you like to work for one of the world's leading online gambling groups? (JA62) 
Five of the interrogative utterances either imply or introduce descriptions of the requirements, qualifications and responsibilities that the job entails.

The majority of the interrogative micro-acts found in the corpus are of a highly emotional and/or evaluative nature. Although it would be risky to classify them as Expressives, some of them do indirectly express enthusiasm, admiration, delight, or at least extremely positive evaluation, typical of persuasive discourse (cf. Łącka-Badura, 2011).

\subsection{Declaratives and Expressives}

No typical Declaratives and Expressives have been identified in the announcements analysed. Although 3 instances of (identical) utterances making use of the expressive verb to regret have been found, their illocutionary point is far from expressive. They might plausibly be rephrased as: We inform ...; the verb to regret has most probably been used to increase the level of politeness:

(25) We regret we can only accept applications from persons authorised to work within the UK. (JA85)

It may be concluded that the class of Declaratives is absent in the corpus, whereas the expressive illocutionary point is realised indirectly, as indicated earlier in this section.

\section{5. 'Complex' speech acts}

Few of the speech acts classified in the previous sections into Searle's prototypical categories can unequivocally be ascribed one and only one illocutionary point. Yet, a separate category of as many as 136 acts, for the purposes of this study named complex, has been distinguished to briefly demonstrate the presence of utterances comprising several micro-acts and having ambiguous or manifold illocutionary points. The following example provides a good illustration:

(26) An exciting opportunity has arisen for a solicitor to join a small, but rapidly growing corporate entity. (JA93) 
Taking into consideration the context of job advertising, the above utterance might perform at least three illocutionary acts: stating/ informing (that we have an opening for a solicitor), expressing enthusiasm / delight about the vacancy (it is exciting), boasting about the organisation (it is small, but rapidly growing). The overall function of the utterance seems to be that of encouraging potential candidates to apply, which is the case in most of the complex, multifunction speech acts identified in the corpus. This broad category covers such a variety of examples, opening a multitude of pragmatic interpretations, that analysing them in detail would go far beyond the scope of this paper, and thus is intended for further research.

\section{Concluding remarks}

The above analysis demonstrates that the majority (over 60\%) of the microspeech-acts identified in the corpus have the syntactic and semantic structure of Representatives, their illocutionary points being those of informing, describing, stating, asserting and boasting. While the former four types of micro-acts confirm the informative dimension of the macro-act of job advertising, the latter (constituting over $14 \%$ of the acts in the corpus) is inherent to persuasive discourse, and thus enhances the persuasive appeal of recruitment ads. Approximately $6 \%$ of the Representatives perform the acts classified as Commissives, particularly promises or offers, typical of persuasive communication. The commissive micro-acts of offering and guaranteeing, as well as the directive acts of instructing, are explicitly performed in only a minority of the instances considered, whereas Declaratives and Expressives are virtually absent in the corpus. Almost $13 \%$ of the micro-acts found in the sample have been classified as 'complex', realising more than one illocutionary point, mostly contributing to the overarching goal of encouraging candidates to apply.

Overall, a large proportion of the micro-acts identified in the corpus (almost $45 \%$ ) are performed indirectly, either within one of the categories proposed by Searle (particularly boasting realised through the acts of informing and stating) or, in the majority of cases, across the categories (particularly the 'complex' acts, as well as assertions acting as promises and offers). As indicated at several points in the analysis, such a high level of indirectness seems to reflect, in the first instance, the persuasive aspect of job advertisements; 
it also serves (albeit to a lesser degree) the politeness function in the recruitment advertising discourse.

\section{Bibliography}

Asher N., Lascarides A., 2001, Indirect Speech Acts, Synthese 128, p. 183-228.

Austin J. L., 1975, How to do things with words. Second edition, Cambridge, MA: Harvard University Press.

Bazerman C., 2004, Speech Acts, Genres, and Activity Systems: How Texts Organize Activity and People., in: C. Bazerman, P. A. Prior (eds.), What Writing Does and How It Does It: an introduction to analyzing texts and textual practices, Mahwah, NJ: Lawrence Erlbaum Associates, p. 309-339.

Brown G. P., 1980, Characterizing Indirect Speech Act, American Journal of Computational Linguistics 6 (3-4), p. 150-166.

CAP P., 2010, Pragmatics, Micropragmatics, Macropragmatics, Lodz Papers in Pragmatics 6 (2), p. 195-228.

Cooper D., Robertson I. T., Timline G., 2003, Recruitment and Selection: A Framework for Success, London: Thomson Learning.

Hernandez L. P., 2001, The Directive-Commissive Continuum, Miscelanea: A Journal of English and American Studies 23, p. 77-98.

Levinson S. C., 1983, Pragmatics, Cambridge: Cambridge University Press.

ŁącKa-BAdura J., 2011, Między ogłoszeniem a reklamą - językowe mechanizmy perswazji w tekstach ogłoszeń rekrutacyjnych, in: M. Łukasik (ed.), Język bez granic, Warszawa: Koło Naukowe BAJT, Uniwersytet Warszawski, p. 36-47.

Meurs F. van, 2010, English in Job Advertisements in the Netherlands: Reasons, Use and Effects, Utrecht: LOT.

Mey J. L., 1994, Pragmatics. An Introduction, Oxford: Blackwell Publishing.

Searle J., 1970, Speech Acts. An Essay In the Philosophy of Language, Cambridge: Cambridge University Press.

Searle J., Vanderveken D., 1985, Speech Acts and Illocutionary Logic, in: J. Searle, D. Vanderveken (eds.), Foundations of Illocutionary Logic, Cambridge: Cambridge University Press, p. 109-132.

Secord H., 2003, Implementing Best Practices in Human Resources Management, CCH Canadian Limited.

SkowroneK K., 2001, Reklama. Studium Pragmalingwistyczne, Wyd. 2, Kraków: Rabid.

SoкoŁowska O., 2001, A Cognitive Study of Speech Acts, Gdańsk: Wydawnictwo Uniwersytetu Gdańskiego.

ToKarz M., 2006, Argumentacja, perswazja, manipulacja, Gdańsk: GWP. 
Witczak-Plisiecka I., 2009, A Note on the Linguistic (In)Determinacy in the Legal Context, Lodz Papers in Pragmatics 5 (2), p. 201-226.

Yule G., 1996, Pragmatics, Oxford: Oxford University Press.

\section{Realizacja pośrednich aktów mowy w internetowych ogłoszeniach rekrutacyjnych}

(streszczenie)

Niniejszy artykuł poświęcony jest analizie mikroaktów mowy w tekstach internetowych ogłoszeń rekrutacyjnych, ze szczególnym uwzględnieniem aktów realizowanych pośrednio oraz celów, jakim owa pośredniość może służyć. Badanie obejmuje 100 ogłoszeń, z których 60 pochodzi z internetowych wydań brytyjskich gazet codziennych, a pozostałe $40-\mathrm{z}$ internetowych portali pracy. W analizie przyjęto założenia metodologiczne wynikające z podejścia kognitywnego: 'klasyczną' typologię aktów mowy według J. Searle'a potraktowano jako kategoryzację prototypów mającą ułatwić organizację badania i zwiększyć jego przejrzystość. Analiza wykazała, iż prawie połowa badanych mikroaktów realizowana jest pośrednio. Najliczniejszą kategorię wśród pośrednich mikroaktów stanowią asercje oraz 'złożone'/ wieloznaczne akty realizujące funkcje chwalenia się i obiecywania, wzmacniające perswazyjny wymiar ogłoszeń rekrutacyjnych. 
